RACHEL NEIS

University of Michigan

\title{
EMBRACING ICONS: THE FACE OF JACOB ON THE THRONE OF GOD*
}

\begin{abstract}
Rachel Neis' article treats Hekhalot Rabbati, a collection of early Jewish mystical traditions, and more specifically $\$ \S 152-169$, a series of Qedusha hymns. These hymns are liturgical performances, the highlight of which is God's passionate embrace of the Facob icon on his throne as triggered by Israel's utterance of the Qedusha. \$ 152-169 also set forth an ocular choreography such that the gazes of Israel and God are exchanged during the recitation of the Qedusha. The article set these traditions within the history of similar Fewish traditions preserved in Rabbinic literature. It will be argued that $\$$ 152-169 date to the early Byzantine period, reflecting a Jewish interest in images of the sacred parallel to the contemporaneous Christian intensification of the cult of images and preoccupation with the nature of religious images.
\end{abstract}

Bear witness to them

of what testimony you see of me,

of what I do to the features of the face of Jacob their father,

which is engraved for me on the throne of my glory.

For at the time that you say before me "holy,"

* I owe a great debt of gratitude to Steven Fine for the exhaustive and constructive criticism and advice that he offered at each stage of this article's production. My thanks go to the participants of the Religions of Late Antiquity Workshop, Princeton University, on "Making Selves and Marking Others: Heresy and Self-Definition in Late Antiquity," (Fall 2005) for their responses to the earliest version of this paper. I am especially grateful to Holger Zellentin and Peter Schäfer for their copious comments and encouragement. My appreciation goes to the anonymous readers of this article for their helpful corrections and critique. Thanks to Ra'anan Boustan for his careful reading of this piece and for his generous observations and conversation. Finally, many thanks go to Madeline Kochen for helping me to clarify my thoughts and the literary expressions thereof. All errors are mine.

Heikhalot Rabbati, § 164, Peter Schäfer, ed., Synopse zur Hekhalot-Literatur, (Tübingen: Mohr, 1981).

2 Indeed, the same thinking has often been applied to the relationship between Judaism and Christianity more generally speaking. See Daniel Boyarin, Dying for God: Martyrdom and the Making of Christianity and Judaism, (Stanford: Stanford University Press, 1999) and Borderlines: The Partition of FudaeoChristianity, (Philadelphia: University of Pennsylvania Press, 2004) for a deconstruction of the binary pair "Judaism/ Christianity." See also the essays in The Ways That Never Parted: Jews and Christians in Late Antiquity and the Early Middle Ages,
I bend over it, embrace, kiss and fondle to it, and my hands are upon its arms, three times, when you speak before me "holy." As it is said: holy, holy, holy. ${ }^{1}$

Heikhalot Rabbati, § 164

For over a century, scholars conceived of the relationship between visuality in Judaism and Christianity in binary terms. ${ }^{2}$ Judaism was understood as a religion of the word in opposition to Christianity, which was seen as a deeply visual culture. For many scholars, never the twain did meet-Jews were always "the nation without art," or "artless," while for much of their history Christians embraced icons, ${ }^{4}$ creating visual representations of the divine. ${ }^{5}$ In less than a decade this constructed chasm has been bridged by scholars presenting ever more nuanced accounts of the formation of Jewish and Christian identities as they pertain to the visual. ${ }^{6}$ Despite these important inroads, the depiction of

eds. Adam H. Becker and Annette Yoshiko Reed, (Tübingen: Mohr Siebeck, 2003)

${ }^{3}$ For these appellations see footnote 6 .

${ }^{4}$ It should be noticed that the term icon, or eikon, is simply one Greek word for image. It is intended here (and in much scholarly literature of this period) to refer to images of the sacred.

${ }^{5}$ The literature on the role of images in Christianity is too vast to cite here. For early Christianity see Robin Margaret Jensen, Understanding early Christian Art, (New York: Routledge, 2000) and the bibliography in Paul C. Finney, The Invisible God: The Earliest Christians on Art, (New York: Oxford University Press, 1994) For Byzantine Christian art, see Robin Cormack, Byzantine Art, (New York: Oxford University Press, 2000) Still excellent resources are André Grabar's, Christian Iconography: a Study of its Origins, trans. Terry Grabar, (Princeton: Princeton University Press, 1968) and his Early Christian Art; from the rise of Christianity to the death of Theodosius, trans. Stuart Gilbert and James Emmons, (New York: Odyssey Press, 1969). For a corrective to the notion that Christians opposed images in the first centuries due to inheriting a "rigorism" inherited from the Jews, see Finney.

${ }^{6}$ For recent work on Jewish visuality and art see Kalman P. Bland, The Artless Few: Medieval and Modern Affirmations and Denials of the Visual, (Princeton: Princeton University Press, 2000); Margaret Olin, The Nation Without Art: Examining Modern 
the Jew as iconophobe has proven remarkably durable, particularly in analyses of Jewish culture in the early Byzantine period. ${ }^{7}$

Starting in the sixth and seventh centuries, Christians debated about visual and material representations of the sacred. In some of the pro-icon dialogues and narratives that date to this period, the Jew was invoked as an attacker of Christian images and image treatment. ${ }^{8}$ The Jewish iconophobe was presented as attacking the veneration of images on the basis of the Bible's prohibition against idolatry. Even those scholars who have cast doubt upon these sources as accurate representations of contemporaneous Jews have not necessarily placed them next to Jewish articulations about the investment of sanctity in images. ${ }^{9}$

Discourses on Fewish Art, (Lincoln: University of Nebraska Press, 2002). See relevant discussion and bibliography in the two latter works (Bland and Olin) on scholarly historical and art historical binaries about Jews, Christians and art. See Catherine Soussloff, Fewish Identity in Modern Art History, (Berkeley: University of California Press, 1999). Most recently Steven Fine has reopened the discussion on the relationship between art and Judaism in late antiquity. See Steven Fine, Art and Judaism in the Greco-Roman World: Towards a New Fewish Archaeology, (Cambridge: Cambridge University Press, 2005). Fine understands Jewish conceptions of art to have been fashioned differently in different periods and environments, allowing the creation of shifting and permeable boundaries through the categories of "idolatry," "forbidden" and "permissible." Using this understanding Fine has managed to get past the red herring that the prohibition against idolatry so often presents. In my own work I have examined visuality in Rabbinic Culture in Palestine and Persia placing it within the history of late antique visuality. See Rachel Neis, In the Eyes of the Rabbis: Vision and Visuality in Late Antique Rabbinic Culture, (Phd diss., Harvard University, 2007).

By "early Byzantine period" 330 - circa $700 \mathrm{CE}$ is intended. By "Byzantine" the eastern half of the Roman empire is meant. Charles Barber takes the position outlined and accordingly would date the iconoclasm found in the synagogues of Palestine (in particular, iconoclasm directed at living figures in the synagogue of Na'aran) to the same period. See Charles Barber, "The Truth in Painting," Speculum 72, (1997): 19-1036. He believes that the iconoclasm "should be placed within the context of the earlier [than eight century] Jewish-Christian polemic over images," Barber, 1022, f. 11. He thus understands the "Christian representation of the Jews as being opposed to images in the Jewish-Christian disputes written down in the seventh century" (Barber, 1023) as being supportive of the notion that such debate actually occurred and that Jews of that time were in fact iconoclasts. He argues further (ibid.) that "the Jews broke from a broader late-antique visual culture." Against this argument see Fine (esp. Fine, 120-123), who understands Palestinian Jews to have gradually adapted, for a variety of reasons, not the least of which
In this article I suggest that a tradition in Heikhalot Rabbati $\S \S 152-169$, and particularly $\S 164$, should be viewed as a Jewish "contribution" to the Byzantine sixth and seventh century preoccupation with images of the sacred. It is one that upsets the binary inaugurated by the contemporaneous Christian texts. This tradition, in which God relates to the image of Jacob's face, will be set within the history of similar traditions preserved in Rabbinic literature.

The figure of the Jew as iconophobe was a valuable tool in Christian identity formation and the construction of orthodoxy. ${ }^{10}$ It is possible that the Heikhalot tradition is a Jewish attempt to appropriate iconophilic imagery to make claims about Jewish legitimacy in the Byzantine world. It can

was the aniconic sensibility (in religious contexts) of the Islamic powers. I would argue that the Heikhalot text under analysis in the article supports Fine's nuanced reading of the more complex Jewish sensibilities regarding images in the Byzantine period. See Lee Levine, "Between Rome and Byzantium in Jewish History: Documentation, Reality, and the Issue of Periodization," in Continuity and Renewal: Fews and Fudaism in Byzantine-Christian Palestine, ed. L. I. Levine, (Jerusalem; Yad Ben-Zvi, 2004): 7-48.

${ }^{8}$ See e.g. Stephen of Bostra, Contra Fudaeos, preserved in John of Damascus in his Third Oration, $P G$ 77, 217-220, and On the Divine Images, trans. David Anderson, (Crestwood: St. Vladimir's Seminary Press, 1997), 96-96; Pseudo-Athanasius Quaestiones ad Antiochum Ducem, (Migne, PG, 28, 597-709); N. Bontwetsch, ed, Doctrina Facobi, 1910; Gustave Bardy, ed. "Tropaia kata loudaion en Damasko" Patrologia orientalis, vol. 15. (Paris 1927): 189-275, 245; A.C. McGiffert, ed., Dialogue of Papiscus and Philo, (Marburg, 1889). Two seventh century narratives (one about a Christ icon, set in Beirut; the other about an icon of the Virgin Mary set in Egypt) tell of Jews who damage icons, which then miraculously bleed. Both tales end up with the conversion of the Jews. See Sermo de miraculo Beryti edito, (PG 28:797A-805B) and W. H. Worrell, The Coptic Manuscripts in the Freer Collection, (New York, 1923), 370. See E. Kitzinger, "The Cult of Images in the Age Before Iconoclasm," Dumbarton Oaks Papers 8, (1954): 83-149 (especially 98-101); George P. Galavaris, "The Mother of God, "Stabbed with a Knife," Dumbarton Oaks Papers 13 (1959): 229-233; Glen Peers, Sacred Shock: Framing Visual Experience in Byzantium (University Park: Penn State Press, 2004), 46-49.

${ }^{9}$ See e.g. David M. Olster, Roman Defeat, Christian Response, and the Literary Construction of the Few (Philadelphia: University of Pennsylvania Press, 1994), and Averil Cameron, "The Language of Images: The Rise of Icons and Christian Representation," in Diana Wood, ed., The Church and the Arts, Studies in Church History 28, (Oxford: Blackwell Publishers, 1992), 1-42. Barber, however, does invoke a Jewish context through the iconoclasm of the Na'aran synagogue.

${ }^{10}$ See Averil Cameron, "How to Read Heresiology," fournal of Medieval and Early Modern Studies, 33 (2003): 471-492. 
hardly be a coincidence that the "face of Jacob" tradition turns on its head a central Christian motif of image worship. At the very least, this tradition complicates the picture of the relationship between Jews, Christians and the visual in the Byzantine period in a particularly illuminating way. ${ }^{11}$

\section{Heikhalot Rabbati \$§ 152-169}

$\$ 164$ is found among a series of hymns preserved in Heikhalot Rabbati, which is part of a collection of mystical and magical materials known as the Heikhalot literature. The origins of the Heikhalot literature are debated. ${ }^{12}$ Some scholars see the Heikhalot

\footnotetext{
${ }^{11}$ For a pioneering study on visuality in Jewish mysticism see Elliot R. Wolfson, Through a Speculum That Shines: Vision and Imagination in Medieval Fewish Mysticism, (Princeton: Princeton University Press, 1994). For an excellent treatment of visuality in Heikhalot literature see Chapter 3. ibid. Particular mention must be made of Wolfson's rich analyses of the "Jacob image." See e.g. Elliot Wolfson, "The Image of Jacob Engraved Upon the Throne: Further Reflection on the Esoteric Doctrine of the German Pietists," in Along the Path: Studies in Kabbalistic Myth, Symbolism, and Hermeneutics, (Albany: University of New York Press, 1995), 1-62. My approach differs from Wolfson's more diachronic and internalist analysis of the Jacob motif (as he follows it through rabbinic to Heikhalot and other traditions). Approaching Hekhalot Rabbati as a production within a wider (in this case Byzantine) context, allows me to be attuned to the ways in which Hekhalot Rabbati rather radically reconfigures the Jacob image as well as to the ways in which it does so while engaging in a wider discourse about icons and veneration.

${ }_{12}$ An indispensable introduction to the study of Heikhalot materials is that of Ra'anan Boustan, "The Study of Heikhalot Literature-Between Mystical Experience and Textual Artifact,"Currents in Biblical Research, forthcoming. Many thanks to Ra'anan Boustan for sharing this article with me prior to its publication and for the stimulating conversation as I was preparing this article.
}

${ }^{13}$ See note 14. Another point especially emphasized by Peter Schäfer is the continued instability of this body of materials, which underwent revision well into the medieval period and beyond. See e.g. Peter Schäfer, "Tradition and Redaction in Hekhalot Literature," Hekhalot-Studien, (Tübingen: Mohr Siebeck, 1988), 8-16.

${ }^{14}$ Despite the Rabbinic hero-characters and indebtedness to Rabbinic tradition (including the desire for Torah learning and knowledge) that is evidenced in these materials, they seem to have a very different orientation to that in classical Rabbinic culture that signifies of more than just a gap between literary genres. Given the nature of the Heikhalot literature it is hard to situate authorship, circulation, or community. For some of the different views of the producers behind the Heikhalot materials see: Gershom Scholem, Jewish Gnosticism, Merkabah Mysticism, and the Talmudic Tradition (New York: Jewish Theological Seminary of America, 1965); Saul Lieberman, corpus as developing in second century Palestine, though more recent scholarship sees it emerging from a sixth or seventh century (or later) Persian or Palestinian milieu. ${ }^{13}$ The present study supports this last possibility. The Heikhalot corpus contains a complex of materials including liturgies, litanies, adjurations, magical and ritual practices, narratives and even religious law. Rabbinic characters figure in the text and either impart instructions for undertaking, or recount experiences of having undergone, mystical journeys. ${ }^{14}$ These journeys (undertaken by the mystical practitioner, the yored) $)^{15}$ consist of the traversing of the heavenly palaces $(=$ heikhalot $)$, the encounter of various angelic figures,

"The Knowledge of Halakha by the Author (or Authors) of the Heikhalot," in I. Gruenwald, Apocalyptic and Merkavah Mysticism (Leiden: Brill, 1980), 241-244; Ithamar Gruenwald, Apocalyptic and Merkavah Mysticis (Leiden: Brill, 1980); Schäfer, HeikhalotStudien; David Halperin, The Faces of the Chariot, Early Jewish Responses to Ezekiel's Vision, (Tübingen: Mohr Siebeck, 1988); Michael D. Swartz, Scholastic Magic: Ritual and Revelation in Early Fewish Mysticism (Princeton: Princeton University Press, 1996); James R. Davila, Descenders to the Chariot: The people behind the Heikhalot Literature (Leiden: Brill, 2001); Rachel Elior, The Three Temples: On the Emergence of Jewish Mysticism (Oxford: Littman Library of Jewish Civilization, 2004); Ra'anan Boustan, From Martyr to Mystic Rabbinic Martyrology and the Making of Merkavah Mysticism (Tübingen: Mohr Siebeck, 2005). Boustan argues for a postrabbinic Byzantine Palestinian setting for the Heikhalot literature - which certainly would apply to the texts under analysis in this article.

${ }_{15}$ Yored means "descender" (pl. yordim). These figures appear in the text as those who undertake the journey through the heavens are often referred to as "those who descend to the chariot" (yordei merkavah). The precise meaning of the term is disputed, see e.g. Elliot R. Wolfson, "Yeridah la-merkavah" Typology of Ecstasy and Enthronement in Ancient Jewish Mysticism," in Mystics of the Book: Themes, Topics and Typologies, ed. R. A. Herrera, (New York: P. Lang, 1993), 13-44; Annelies Kuyt, The 'Descent' to the Chariot: Towards a Description of the Terminology, Place, Function and Nature of the Yeridah in Heikhalot Literature (Tübingen: Mohr Siebeck, 1995). On the relationship between yeridah la-merkavah (descending to the chariot) and the rabbinic (tannaitic) expression for leading the community in prayer, yored lifnei ha-teva (lit. "going down before the torah cabinet), see I. Gruenwald, "The Song of the Angels, the Qedushah and the Composition of the Heikhalot Literature," in Peraqim Be-Toledot Terushalayim Bi- Bayit Sheni: Sefer Zikaron Le-Avraham Shali, eds. Aharon Oppenheimer, Uriel Rappaport, Menahem Stern (Jerusalem: Hotsa'at Yad Yizhak Ben Zvi, 1980), 459-481. See also bibliography cited by Z. Weiss, "The Location of the Sheliah Tsibbur During Prayer," Cathedra, 55 (1990); Ya’akov Elman, "Babylonian Baraitot in the Tosefta and the 'Dialectology' of Middle Hebrew," A7S Review 16 (1991): 23; Jeffrey Hoffman, "The Ancient Torah Service in Light of the Realia of the Talmudic Era," Conservative Judaism, $42(1989 / 1990):$ 42-44. 
and the navigation of heaven in order to behold awesome sights, particularly that of God on his chariot-throne (= merkavah) ${ }^{16}$

The textual unit of Heikhalot Rabbati that will be discussed, numbered $\S \S 152-169$ in the Synopse edition of Peter Schäfer, is one of the units of the "Qedushah Songs." 17 While generally speaking, the constituent elements of the Heikhalot corpus are in a relatively loosely redacted state, Heikhalot Rabbati is one of the more stable textual bodies and $\S \S$ 152-169 manifests this characteristic uniformity.

$\S \S 152-169$ consists of a series of songs praising God on his throne, which end with the Qedushah (sanctification), built around Isaiah 6:3: "Holy, holy, holy is the Lord, God of hosts; the whole earth is full of your glory." "18 This is what the seraphic angels call out to each other while hovering around the enthroned God.

As is characteristic of Heikhalot texts, the vision of God itself is not detailed. Instead we find praise of God, his throne, his various heavenly servants and retinue, and descriptions of the awesomeness and affectivity of the vision rather than its specifications, all punctuated with rapturous eruptions.

An example is the enthusiastic invocation of God's throne in $\S 154$.

Jubilate, jubilate, uppermost seat.

Shout, shout, precious object,

that is made wonderfully and is a wonder.

gladden, gladden, King who is on you,

as the joy of a bridegroom in the his wedding chamber.

Let the whole seed of Jacob be glad and be merry.

And when I came to find shelter under the shadow of your wings

With gladness of the heart which is glad with you ... As it is said: Holy, holy, holy is the Lord. ${ }^{19}$

\footnotetext{
${ }_{16}$ This latter vision of the chariot-throne (giving rise to the term "merkavah mysticism") derives from the vision of God's chariot in Ezekiel 1 and 10 and Daniel 7.

${ }_{17}$ See Kuyt's division of Heikhalot Rabbati into subdivisions. Kuyt, The 'Descent', 125-130.

${ }_{13}^{13}$ See Peter Schäfer, "The Hidden and Manifest God. Some Major Themes in Early Ferwish Mysticism (Albany: State University of New York Press, 1992), 24 n. 52: "[T]he trishagion [thrice holy] from Isaiah 6:3 must not necessarily be the Qedushah in the technical sense. This is true especially of the so-called Qedushah songs (sections 94-106 and 152-169), in which the trishagion is more likely a means of formally structuring the text." In $\S \S 152-169$, the Qedushah seems to be more than just a literary device, bearing as it does rather substantive import as structured around §164. See further Schäfer's comments on p. 36 , footnote 106 , on the likelihood that $\$ 152$ is added latterly transitioning between the previous apoca-
}

The throne of God occupies an important place in Heikhalot Rabbati. ${ }^{20}$ The Qedushah hymns seem to take this quite far - the throne is glorified and personified. In $\S 154$ God (the King) is enjoined, almost secondarily, to celebrate the throne. In its wider literary setting, there is something about the throne that gives rise to particular intensity. Significantly, the contact of the throne with its divine occupant is supposed to stimulate the jubilation of Jacob's descendants (more literally, of Jacob's "seed") and to arouse God's celebration of the throne's proximity, a proximity whose intimacy amounts to connubial bliss. ${ }^{21}$ This erotic imagery prefigures God's actions over Jacob's face, which is described in $\S 164$ and is located on the throne (that "precious object" which is "made wonderfully and is a wonder.")

It is in a similarly allusive fashion that $\$ 159$ piles on praises of the face:

Lovely face

Adorned face

Face of beauty

Face of flame[s]

is the face of the Lord, the God of Israel,

when he sits upon his throne of glory.

And his honor awaits him on his embellished seat. His beauty is more lovely

than the beauty of the gevurot [powers = angelic creatures]. His embellishment is more exquisite

than the embellishment of the bridegroom and bride in their wedding chamber.

Here, the "lovely face, adorned face, face of beauty, face of flame," is described in nuptial terms ("his/its embellishment is more exquisite than the embellishment of the bridegroom and bride in their

lyptic passages and the beginning of the Qedushah Songs proper. On the Qedushah in the synagogue, see J. Heinemann, Prayer in the Talmud: Forms and Patterns (Berlin: de Gruyter, 1977), 24, 230-233. On the possible derivation of the Apostolic Constitutions, see D. Fiensey, Prayers Alleged to be Fewish: an Examination of the Constitutiones Apostolorum (Chico, Calif.: Scholars Press, 1985). See recently, Lee Levine, The Ancient Synagogue: The First Thousand Years (New Haven: Yale University Press, 2000), 540-544.

${ }_{19}$ MS. B238. See MS. N8128. Cf. throne references in $\$ 153$.

${ }^{20}$ See $\S \S 94,153,154,634,687$. See P. Schäfer, "The Hidden" 11 , where he suggests that this throne preoccupation is special to Heikhalot Rabbati, which has its own "throne theology."

${ }_{21}$ The appellation of "Jacob's seed" for Israel, or for that matter of Isaac or Abraham's "seed," is not by itself significant. My argument is that it derives significance in this particular literary setting. 
wedding chamber.") The reference in $\S 159$ to "the face of the Lord the God of Israel, when he sits upon the throne of his glory," while not an unexpected formulation, alludes to the throne and the specifically facial beauty that belongs to it. ${ }^{22}$ That is, while the face being praised here is ostensibly the divine countenance, I suggest that, in this instance, it is synonymous with Jacob's face. ${ }^{23}$

The continuation of $\S 159$ describes the consequences to the angelic servants of being exposed to such sights, sustaining the theme that is found throughout Heikhalot Rabbati of angelic-human rivalry:

He who looks at it

will immediately be torn.

He who views its beauty

will immediately be poured out like a jug.

Those who serve him today

will no longer serve him tomorrow.

And those who serve him tomorrow

will no longer serve him.

For their strength disappears

and their faces become obscure.

Their hearts are led astray,

and their eyes become darkened,

due to the embellishment

of the radiance of the beauty of the king.

As it says holy, holy, holy.

The angelic-human rivalry is partly a struggle about who has privileged access to the sight of God. ${ }^{24}$ Here the deleterious effects of gazing at God are placed firmly in the angelic province - the angels are singled out as susceptible to being singed by exposure to God's beautiful face.

The model of vision presented, in marked contrast to the angels' blinded eyes and singed faces of $\S 159$, is that of the "happy eye" of the descender who beholds the revolutions of God's chariot in $\S 160$ :

Beloved ministers, pleasing ministers ...

Who stand around the throne of glory

and who gather around the wheel of the chariot.

When the stone [of] the throne of glory twists around them,

the throne, the wheel of the chariot seizes them.

[Those standing on the right go back and stand on the left

And those standing on the left go back and stand

\footnotetext{
${ }^{22}$ As per Kuyt, "The 'Descent', 173.

${ }^{23} \mathrm{I}$ also argue that it points towards $\S 164$ and $\$ 169$.

${ }^{24}$ See P. Schäfer, "The Hidden," 139-147; Schäfer, Rivaltät zwischen Engeln und Menschen: Untersuchungen zur rabbinischen
}

on the right.

And those standing in front return and stand behind And those standing behind return and stand in front.] ...

One whose see this one says that is him, and one who sees that one says that is him.

[For] the cast of the face [qlaster] of this one is like the cast of face of this one.

And the cast of the face of the other is like the cast of face of the other one.

Happy is the king whose ministers are these

Happy are the ministers whose King is this one.

Happy is the eye which is nourished and which beholds ${ }^{25}$

this wondrous light

Sight wondrous and strange.

As it says: holy, holy, holy.

The darkened eyes of the angels [ונחשבו עיניהם] are more than counterbalanced by the happy human "eye that is nourished" [עין הניזונת] by this unusual sight [רייה].

The Qedushah hymns also offer other models of vision: that of the mutual gaze between God and Israel and that of the voyeuristic look of the yored. The former is set in $\S 163$. Vision, here, is mutual and interactive:

Blessed by heaven and earth, descenders to the chariot, If you will say and tell my children

what I do [מה אני עושה]

during the morning prayer and during the afternoon and evening prayer,

and on every day and at every time that Israel is saying "holy" before me.

And teach them, and say to them:

Lift up your eyes to heaven [שאו עיניכם לדקיע],

facing your house of prayer

at the time when you are saying "holy" before me.

Because I do not have pleasure in the whole house of my world which I created

[except] during that time

in which your eyes are lifted up to my eyes [עיניכם נשואות בעיניי

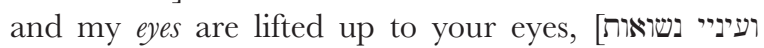
] בעיניכם

at the time in which you say "holy" before me.

Because everything that comes out of your mouths at that time runs on and ascends before me as a pleasing smell. ${ }^{27}$

\footnotetext{
Engelvortstellung (Berlin: De Gruyter, 1975).

${ }^{25}$ An allusion to Ex. 24:9-10.

${ }^{26}$ We are not told what God actually does until $\S 164$.

$27 \S 163$.
} 
The descenders here are charged to transmit what they see, ${ }^{28}$ and are also given instructions that will enable Israel below to interact in an ocular fashion with God. ${ }^{29}$ This is choreographed with some specificity: Israel must raise their eyes heavenwards above their synagogue when they are about to utter the Qedushah ("lift up your eyes to heaven opposite your house of prayer"). ${ }^{30}$ Somehow, to God's most profound pleasure, their eyes are locked in his ("your eyes are lifted up to my eyes"), and his eyes are locked in theirs ("my eyes are lifted up to your eyes"). ${ }^{31}$ Exactly how this is accomplished is elided.

The movement of the eyes in the synagogue and in heaven occurs simultaneously, ensuring their meeting. ${ }^{32}$ God and Israel's reciprocal gazes traverse the distance across the realms of heaven and earth. ${ }^{33}$ The divine desire for Israel's praise and gaze highlights their privileged position. Even the yored might only witness; his signal instruction is to facilitate an event that happens in the heavens and in the liturgical space of the terrestrial synagogue. ${ }^{34}$ The task of the yored is secondary to the ocular communion that occurs between Israel and
God and that is effectuated by the correct manner of reciting the Qedushah. ${ }^{35}$

With the recession of the yored's role, the "goal" is clearly not that of obtaining a vision of God. Rather, the ocular desire is attributed to God, and the motivating drive is his wish to behold (and, as we shall see, to hold) and to be beheld by Israel during the performance of the Qedushah liturgy. ${ }^{36}$

The visual is the medium that is emphasized, but the experience is multi-sensory and encompasses sound and smell ("Because everything that comes out of your mouths at that time runs on and ascends before me as a pleasing smell." $)^{37}$ This actually reinforces the liturgical logic of the section, which moves (via speech and scent) from the mouths of those in the synagogue space to the implied ears and nose of God in the heavenly realm. These sensory media travel across distances much in the manner of the ocular gazes of God and Israel. The liturgical and performative senses of the text are dramatized in heightened fashion in $\S 164$ as God continues to instruct the descender: ${ }^{38}$

Bear witness to them

of what testimony you see [רואים] with me,
${ }^{28}$ The content of what God does ("what I do [מה אני עושה]") is left untold until $\S 164$, where the same language is employed but this time with elaboration.

${ }_{29}$ This is an abrupt transition from an implied narrator's description of the praise rushing towards God's throne in the previous $\S 162$.

${ }^{30}$ Liturgically summoning a "dome of heaven" such as that represented in architectural space in the Pantheon or the Hagia Sophia. On the Pantheon, see Cassius Dio, Roman History, 53.27.

31 Compare with $\S 159$ where the angelic gaze of God's beauty leads to the darkening of their eyes.

${ }^{32}$ Regarding the importance and changing iconography of eyes and gaze in portrait icons see Jens Fleischer, "Style as Bearer of Meaning. The Transition from Late Antique Mummy Portraits to Early Icons," in Late Antiquity: Art in Context, eds. Jens Fleischer, Marjatta Nielsen, John Lund, (Copenhagen: Museum Tusculanum Press, 2001), 53-70. See further, H. P. L'Orange, Apotheosis in Ancient Portraiture (New York: Caratzas Bros., 1982) and G.B. Ladner, Ad Imaginem Dei; the Image of Man in Mediaeval Art, (Latrobe, Pa: Archabbey Press, 1965), 74.

${ }^{33}$ On reciprocal vision in classical Greek culture see Françoise Frontisi-Ducroux, Du Masque au Visage. Aspects de l'identité en Grèce ancienne, (Paris: Flammarion, 1995).

${ }^{34}$ Suggesting that the Qedushah hymns are what should be uttered for the purposes of descending to see the Chariot, Schäfer goes on to propose that these hymns "point [...] to a definite liturgical Sitz im Leben of the heavenly journey, which does not necessarily exclude ecstatic implications, but makes them relatively unlikely." My analysis of this section of the Qedushah hymns supports the notion that these are texts designed for a liturgical context.

${ }^{35}$ Here I would differ with Peter Schäfer's interpretation of this passage. He argues, in The Hidden, 45, that the yored is both intermediary and representative of Israel, but in my analysis the yored functions as a witness, a voyeuristic observer of what is the true center of action, i.e. that which takes place between God and Jacob/Israel's face (translating or paralleling the ocular communion between God and the praying Israel.)

${ }^{36}$ See Schäfer on the distorting effect of seeking one governing "goal" of the Heikhalot corpus, The Hidden, 9.

37 See Psalms 141.2. For the importance of the multi-sensory liturgical context in which the icon was viewed and venerated see Liz James, "Senses and Sensibility in Byzantium," Art History, 4 (2004): 522-37; Béatrice Caseau, Euodia, the Use and Meaning of Fragrances in the Ancient World and their Christianization (100-900 AD), (PhD diss.: Princeton University, 1994), "Christian Bodies, the Senses and Early Byzantine Christianity", Desire and Denial in Byzantium, ed. Liz James. (Aldershot, Brookfield, Vt: Ashgate/Variorum, 1999), 101-109.

${ }^{38} \mathrm{My}$ analysis of this section of the Qedushah hymns supports the notion that these are texts designed for a liturgical context (as per Schäfer's proposal). My thanks to Peter Schäfer for pointing out the importance of the earliest dated Geniza fragment for this aspect of my argument, as well as for my situating this section in a Byzantine environment. See Peter Shäfer, ed., Geniza-Fragmente zur Heikhalot-Literatur (Tubigen: Mohr Siebeck, 1984), 9-32. This fragment, 1.T.-S K21.95.S, which includes Qedushah hymns (e.g. $\S \S 94-95=\S \S 154-155)$, 
of what I do [מה אני עושה]

to the cast of the face [לקלסתר פניי] of Jacob their father, ${ }^{39}$

which is engraved for me [שהיא חקוקה לי]

on the throne of my glory.

For at the time when you say before me "holy," I bend over it [כורע אני עליה], embrace, kiss and fondle it [ומחבקה ומנשקה ומנפפה], and my hands [are] upon its arms, ${ }^{40}$ three times, when you speak before me "holy." As it is said: holy, holy, holy.

Once again God presents instructions to the yored this time to relay the sight [ריאייה] to Israel. In so doing God spells out what is to be seen; and as a consequence the text also reveals the sights to us (the implied reader or audience) in no uncertain terms. God directs his amorous affections towards the face of Jacob. He drapes himself over it, hugs it, kisses it, fondles it, and, in one manuscript, places his hands on its arms. Even without the attribution of arms to the "face," it is apparent from the actions expressed by the series of verbs, that Jacob's image is sufficiently embodied to receive God's physical attentions. ${ }^{41}$

In $\S 163$ the divine pleasure is chiefly of an ocular nature ("Because I do not have pleasure in the whole house of my world which I created [except] during the time in which your eyes are lifted up to my eyes.") Here, in $\S 164$, the ocular seems to consist in the viewing of God's physical ministrations. The yored is urged to transmit what he sees back to the sons of Jacob down below; this conveyance of visual information seems to be vital to the efficacy of the whole operation, as is the yored's mandate to ensure that Israel's gaze is raised at the right moment when they utter the Qedushah (in § 163). is likely earlier than ninth century. The unusual physical characteristics of this fragment (a scroll) strongly suggest a liturgical Sitz im Leben. See Shäfer, "Geniza-Fragmente," 9.

${ }^{39}$ I translate qlaster as cast, and qlaster panim as "the cast of the face." I mean to evoke both the meaning of cast as arrangement and as an artifact that is made by impression. Crystal [krustallos $=$ ice/transparent] has been suggested as the proper reading of this word by Marcus Jastrow, A Dictionary of the Targumim, the Talmud Babli and Yerushalmi, and the Midrashic Literature (New York: Judaica Press, 1989), 1379. See the use of this word in Genesis Rabba 41:6, 60:7; Leviticus Rabba 18:1, 20:2, Ecclesiastes Rabba 8:2, 12:2, Babylonian Talmud, Bava Metzia 87a. The word qlaster in rabbinic texts describes the identity facial features (e.g. Isaac's and Abraham's). Jastrow views the זיו אקונין [radiance of icon], which is used to mean "features of face," in cases of verisimilitude. While the colloquial "dazzling likeness" would be a tempting translation, it seems that the "radiance" is still more a property of the "face." (The notion of visual and physical resemblance focuses on the face and its features. In this vein, the face is a synecdoche for the body entire.) We see this sense is borne out above in the $\S$ 160 where the angels in their revolutions are identified as identical images of each other. The importance of verisimilitude preoccupied early Byzantines who used the device of images not made by human hands (acheropoetoi) to authenticate the resemblance and legitimacy of various sacred images. For the argument that the notion that the verisimilitude at stake in the case of Jacob's qlaster panim is that of resemblance to God's divine presence, see Shamma Friedman, "Graven Images," Graven Images 1 (1994): 233-238. This comports with Ra'anan Boustan and Nathaniel Deutsch's reading of Sar hapanim as "prince who is the face [of God]" as well as with my reading of the Jacob icon or panim as God's face. See Nathaniel Deutsch, Guardians of the Gate: Angelic Vice Regency in Late Antiquity, (Leiden: Brill, 1999), 43; Deutsch, The Gnostic Imagination: Gnosticism, Mandaeism, and Merkabah Mysticism, (Leiden:
Brill, 1995); Boustan, Martyr, 118-121. The multiple and overlapping ways in which facial appellations and facial notions of similitude and of beauty are used within Heikhalot writings and without (in Rabbinic and Byzantine texts, in iconographic representations that focus on the holy figures face and eyes) enhances the valences summoned in God's gestures towards the qlaster panim of Jacob.

${ }^{t 0}$ According to MSS Vatican 228 and Munich 22; the remainder of MSS in the Synopse have "my arms."

${ }^{41}$ On God's arms resting on Jacob's (or his own) see Elliot Wolfson, Through a Speculum that Shines (Princeton: Princeton University Press, 1994), 101, who suggests that the arms referred to here are those of the throne. See also Peter Schäfer, The Hidden, 119. I suggest below that here we have a biblical allusion to Jacob. It is conceivable that the "face of Jacob" is used in a more generic sense for Jacob's image or likeness and could include a representation of his entire figure or bust. The bust, or portrait medallion, was ubiquitous in civic, funerary and religious art in Late Antiquity and Byzantine periods, and while emphasizing the face of the person portrayed could portray the upper torso and arms. Finally, over time the iconography of the Virgin Mary included her depiction/designation as the Throne of Wisdom/Solomon upon which the Christ child sat. See A. D. McKenzie, "The Virgin Mary as the Throne of Solomon in Medieval Art." (PhD diss. New York University, 1965). In this conception, the figure and the throne are one; thus the arms of the throne are the arms of the figure. Exegetically, this tradition goes back to the fourth century Athanasius and Methodius. See Methodius, Oration concerning Simeon and Anna, II.5, 11. For Byzantine throne iconography originating in the pre-Iconoclastic period that still remains, see the mosaics in St. Catherine's Monastery at Mt. Sinai. Kurt Weitzman sets this apart from those preserved in Ravenna which are not seen as "pure Byzantine" iconography, "which are a mixture of Byzantine and Italian styles." See Kurt Weitzman, The Monastery of Saint Catherine at Mount Sinai: the Icons, (Princeton: Princeton 
This somewhat mysterious relationship between the mutual gaze and interaction with an image actually coincides with something of the complexity of Byzantine theories of vision, and particularly, of looking at sacred images. Anastasius Sinaita, the seventh century abbot of the monastery of St. Catherine at Mt. Sinai, spoke of the way in which the eyes of an icon seems to transmit the gaze of Christ from above, as well as how this stimulates a ritual response, "And if we see only the image of His divine form, as if he were gazing down at us from heaven, we prostrate in veneration. ${ }^{42}$ In this instance, the reverse happens; God gazing (from afar) into the eyes of Israel/Jacob is brought to venerate his image of Jacob.

$\S 164$ deploys motion, touch, space and the auditory as elements in the divine liturgical performance. The rhythm of God's actions matches the thrice-chanted holy praise of Israel. Each "holy," triggers the four (or five) sequential gestures towards Jacob's face. ${ }^{43}$ The iterative nature of God's performance also promotes a ritualistic and ceremonial tone.

Allusions and direct invocations of Jacob scattered throughout this unit are animated. The jubilation of "the seed of Jacob" upon God taking his seat on the throne - the throne that is in fact the bearer of the image of Jacob-also activates the imagery of connubial splendor of the face that is set forth in $\S 157$. This performance represents the climax of this textual unit and the interpretive axis around which it spins. The Jacob icon, as I have called it, had a long career in Rabbinic literature of late antiquity. In order to appreciate the significance of Jacob's face and to a lesser extent, of the nature of the iterative

University Press, 1976), 405. On carved thrones such as that of the sixth century Bishop Maximian at Ravenna and on ivory carvings see Charles Rufus Morey, "The Early Christian Ivories of the Eastern Empire," Dumbarton Oaks Paper, (1941): 41-60.

${ }^{42}$ This fragment comes to us from a passage quoted by John of Damascus in his Third Oration, PG 94 1416C. See St. John of Damascus, On the Divine Images, trans. Anderson (Crestwood, N.Y.: St. Vladimir's Seminary Press, 1980), 99-100.

${ }^{43}$ It is not clear whether by "three times" God attests to his performance of the four-fold actions three times per utterance of "holy" (totaling nine), or he refers to a net total of three, with one series of actions performed once per "holy."

${ }^{44} \mathrm{~J}$. Heinemann called piyyut, perhaps with some exaggeration, "the literature of the synagogue." See J. Heinemann with Joseph Petuchowski, Literature of the Synagogue (New York: Behrman House, 1975). ritual that God performs in Heikhalot Rabbati, it is necessary to enter into the interpretive history of the Jacob image [איקוני] that is engraved [הקוקה] upon God's throne.

\section{The Jacob Icon in Rabbinic Tradition}

The notion that Jacob's features were engraved on God's throne is found in midrashic sources, Targumim and liturgical poetry (piyyut). ${ }^{44}$ It primarily attaches to interpretations of Jacob's vision in Genesis 28:12 but is also hung on other exegetical hooks. ${ }^{45}$ The interpretive history enjoyed by Jacob's vision at Beth-El tended, not unlike the visualization in Heikhalot Rabbati, to be just as much about what is seen of facob as about what Jacob sees.

An example of this visual focus is found in Genesis Rabba on Genesis 28: $12-13 .^{46}$ Genesis Rabba, a classical Palestinian Midrash, was redacted during the fifth century. I present the translation of the biblical verses with possible alternatives in parentheses.

And he dreamed.

And behold a ladder set up on the earth, and its (his) top (head) [rosh] reached heaven.

And behold the angels of God were ascending and descending on it (him).

And, behold, the Lord stood over it (him).

According to Genesis Rabba, the subject of "and its (his) top (head) reached heaven" is also the subject of the first clause, i.e., Jacob ("his"), rather than the ladder ("its.") The word rosh allows the meaning top or head. ${ }^{47}$ Thus, even within the

${ }^{45}$ The association of Jacob with God's face derives from its biblical thematization of the struggle at Jabbok. See Gen. 32.22-32. See Elliot R. Wolfson's rich analysis of Midrashic and Targumic traditions about Jacob's face on God's throne in The Face of Facob.

${ }^{46}$ J. Theodor and Ch. Albeck, eds., Midrash Bereshit Rabba: Critical Edition with Notes and Commentary, Jerusalem: Wahrmann Books, 1965). For a description of Genesis Rabba as well as discussion of dating and redaction see H.L. Strack and G. Stemberger, Introduction to the Talmud and Midrash, trans. Markus Bockmuehl (Minneapolis: Fortress Press, 1992), 300-308.

${ }^{47}$ See James L. Kugel, The Ladder of Facob: Ancient Interpretations of the Biblical Story of Facob and His Children (Princeton: Princeton University Press, 2006), 16-17. See also his analysis of the second temple roots of the Slavonic Ladder of Facob, in "The Ladder of Jacob," Harvard Theological Review, 88, 2 (1995): 209-227. 
syntactical limits of the biblical words the following (somewhat surprising) sense can be extracted: "While Jacob dreamed, a ladder emerged with Jacob's head at its heavenly peak." In similar fashion the remainder is understood as follows: "the angels of God were ascending and descending on him (i.e. the Jacob up above, and his sleeping form below). And, behold, the Lord stood over him (i.e. over the face of Jacob)." ${ }^{48}$

These biblical phrases offer Genesis Rabba the opportunity for further narrative motivation and embellishment. Here the midrash does so, on the words, "And behold, the Lord stood over him."

Rabbi Hiyya the Great and Rabbi Yannai differed. One said: they were "ascending and descending the ladder;" the other said: they were "ascending and descending over Jacob." [...] The statement that they were "ascending and descending over Jacob" must mean that some were exalting him and others degrading him, dancing, leaping, and despising him. Thus it says, "Israel in whom I will be glorified" (Isaiah 49:3). It is you whose features are engraved on high. They ascended on high and saw his features and they descended below and found him sleeping. ${ }^{49}$

R. Yannai's view extracts two complementary shades of meaning, one from "ascending and descending" and one from "over him." Thus, the angels are understood to have gone up and down to see heavenly and earthly forms of Jacob. The former, "whose features are engraved on high," is that through which God is glorified above and is also that which gives rise to angelic exultation (ascent), whereas the latter, lower, sleeping figure is a source of derision and disdain (descent). One thinks of Jacob as depicted in the Dura Europos synagogue (unfortunately the upper part of the

${ }^{48}$ Genesis Rabba 68:12. Cf. Targums Neophyti and PseudoJonathan on Genesis 28.12.

${ }^{49}$ Genesis Rabba 68.12. The midrash continues: It may be compared to a king who sat and judged in a judgment chamber; people ascend the basilica and find him sleeping, they go out to the judgment chamber and find him judging. In heaven, who speaks in his [Israel's] favor is exalted; in his disfavor, is put down, but on earth, he who speaks in his favor is put down; in his disfavor, is exalted.

${ }^{50}$ See Carl H. Kraeling, The Synagogue (New Haven: Yale University Press, 1943), 73. Weitzman and Kessler speculate using various Christian models, e.g. ninth century miniatures that have busts of Christ, that there would be the hand of God. See Kurt Weitzman and Herbet L. Kessler, The Frescoes image is damaged); he lies sleeping while one of the two angels ascending and descending the ladder points at him. ${ }^{50}$ In Heikhalot Rabbati $\S \S 163-164$, the yored, in his mediating role between God and Israel and heaven and earth, fills the role of the angelic ascenders and descenders of the midrash.

Isaiah 49:3, "You are my servant, O Israel, in whom I will be glorified," is invoked as a proof text for Jacob's features being "engraved up above." ${ }_{51}$ Contrasting with, and also echoing, the Jacob tradition, Patristic interpretations have Christ (another image of God) atop the ladder, while reading the stone upon which Jacob slept as the bosom of Christ. ${ }^{52}$

While the notion of God being glorified through Jacob is one that draws from the idea of Jacob as an onomastic and metonymic representative of God, the fuller passage from Isaiah further justifies the visual component of this proof:

And He said to me: "You are my servant, Israel, in whom I will be glorified." And now says the Lord that formed me from the womb to be his servant, to bring Jacob back to him, and that Israel be gathered to him. For I am honorable in the eyes of [בעינ] the Lord, and my God has become my strength. And he said: "It is too light a thing for you to be my servant, to raise up the tribes of Jacob, and to restore the offspring of Israel; I will also give you as a light of the nations that my salvation may be until the edge of the earth." So said the Lord, the redeemer of Israel, his Holy One, to him who is despised of men, to him who is abhorred of nations, to a servant of rulers: "Kings shall see and arise, princes, and they shall prostrate themselves; because of the Lord that is faithful, even the Holy One of Israel [קדש ישראל], who has chosen you. ${ }^{53}$

of the Dura Synagogue and Christian Art, (Washington, D.C.: Dumbarton Oaks Research Library and Collection, 1990). James Kugel points out that these interpretations assume that the sleeping Jacob and the ladder with angels are both actually happening in real time. That is to say, the ladder and angels are not the content of Jacob's dream. See Kugel, "The Ladder," 15.

${ }^{51}$ The Slavonic Ladder of Facob contains this tradition, in exponentially iconic form, with busts of icons mounted on every step of the ladder to heaven. See Kugel, "The Ladder," who believes that the original Hebrew text dated back to the second temple period.

${ }^{52}$ See John 1:50-51 and Justin Martyr, Dialogue with Trypho, 60.

${ }^{53}$ Isaiah 49:3-7. 
The visual language of these verses also offers opportunities for anchoring the idea of the Jacobimage. ${ }^{54}$ Furthermore, the narrative elements of the midrashic traditions can be found in this passage. Here we find the same combinations of the contempt and veneration that the angels direct toward Israel/Jacob, as well as of Israel/Jacob being the one through whom God is glorified (and by whom God is called) while being one reviled..$^{55}$ Instead of angels it is men and nations who disdain Jacob/Israel but who are then brought to venerate him. ${ }^{56}$ Of course, this passage became an important source for Christian interpreters, who saw the "Suffering Servant" as a prefiguration of Christ in the Hebrew Bible. In the Heikhalot Rabbati case, the worship of the nations and angelic praise becomes God's worship for Israel/Jacob's icon. Indeed, the inversion of status, from lowly to elevated, expressed by "kings shall see and arise, princes, and they shall prostrate themselves" bears a resemblance to the surprising role-reversal of God's worship of his people through Jacob. It is this feature (of reversing worshiper/worshipped roles) in Heikhalot Rabbati that represents a significant departure from these other, earlier, uses of the Jacob image.

The Jacob image is deployed more sharply in terms of angelic-human rivalry in its use in the Babylonian Talmud, tractate Hullin, folio 91b:

\section{A Tanna taught:}

They ascended to look at the image [דיוקניאן above and descended to look at the image [דיוקמא[ below. They wished to hurt him, when, "Behold, the Lord stood over him." ${ }^{258}$

The parallelism and the iconic language of the Talmud heighten the visual parallelism of the

\footnotetext{
${ }^{54}$ E.g. "For I am honorable in the eyes of the Lord," and " "Kings shall see and arise, princes, and they shall prostrate themselves."

${ }_{55}$ See Lamentations Rabba 2.2 where God accuses Israel of taking advantage of the presence of this icon and provoking him with their behavior. He threatens to cast down the icon of Jacob from his throne.

${ }^{56}$ Compare the choreography of veneration on the part of kings and princes of nations here to that of God in $H R$ $\S 164$. On a related note, it is interesting to see how the Rabbis treat a passage that was of such import for Christian exegetical projects of prefiguring Christ's narrative in the Hebrew Bible. It should also be noted that the midrashic traditions on Jacob's ladder also parse the ascending and
}

earthly and heavenly forms of Jacob. Apparently the earthly version so enrages the angels that their iconoclastic instincts are aroused, but thanks to God's intervention Jacob is saved from hurt. ${ }^{59}$

Genesis Rabba inserts the Jacob icon rather less ambivalently into the biblical verse in which Jacob's battle partner at Jabbok blesses him with a new name: "Your name will no longer be called Jacob but Israel. For you have struggled with God and with men and have prevailed." The midrash, focusing on the clause, "for you have struggled with God," (כי שרית עם אלהים) reads "you rule with God" i.e. "it is you whose features are engraved on high." ${ }^{60}$ That is, not only is Jacob's fighting partner made to recognize Jacob as he whose image is with God, but this realization becomes the source of Jacob's new name. It is significant that this name, "Israel," is also the name by which the "nation" is known.

The Jacob tradition is also associated midrashically with God's appearance via the biblical reference to a theophany that Jacob experiences upon building an altar: ${ }^{61}$

Rabbi Isaac opened: "An altar of earth you shall make for me ... in every place I cause my name to be mentioned I will come to you and bless you (Exodus 20:24)." If I bless the one who builds an altar in my name, how much more should I appear to Jacob, whose features are engraved on my throne, and bless him. So it says, "And God appeared to Jacob ... and blessed him."

Rabbi Levi commenced: "And an ox and a ram for peace-offerings ... for today the Lord will appear to you (Leviticus 9:4)." If I appear to the one who offered a ram in my name and bless him, how much more should I appear to Jacob whose features are

descending angels in terms of the rise and fall of empires under which Israel lives. Edom, the Roman/Christian empire is the last of these. See Kugel's reading in "Ladder."

${ }^{57}$ It has been suggested to me by Madeline Kochen that the image above could conceivably refer to God while the image below refers to Jacob.

${ }^{58}$ On the Babylonian Talmud, see Strack and Stemberger, "Introduction," 208-244.

59 The Talmudic text then launches into a comparison between Israel and the angel's recitation of the Qedushah before the divine throne that favors Israel-another playing out of theme of angelic-human rivalry.

60 Genesis Rabba 68.12

${ }^{61}$ Genesis 35:9. 
engraved on my throne, and bless him. So it says, And God appeared to Jacob ... and blessed him." ${ }^{62}$ It is noteworthy that in the Biblical text it is Jacob's vision of God (rather than the image of Jacob) that is highlighted. Genesis 35 refers back to Chapter 28 (of the ladder and angels) both in explaining that Jacob built the altar "there in the place that God was revealed to him," and in the very phrase under discussion in the midrash, i.e. "And God appeared to Jacob [again] ... and he blessed him." 63 However, both Rabbinic and Heikhalot Rabbati Jacob traditions share the tendency to focus on the seeing of Jacob, whether by God or angels (rather than the seeing of God.)

The Rabbinic texts set up a visual symmetry, between an earthly Jacob and a divine iconic Jacob, which the Heikhalot Rabbati Qedushah hymns apparently take up and expand. ${ }^{64}$ As we have already seen, this symmetry is inaugurated in $\S 163$ with the featuring of Israel in the synagogue, and their heavenly image and representative, Jacob.

$\S 164$ 's indebtedness to Biblical and post-Biblical traditions associating Jacob/Israel with vision and God is clear. Moreover, Jacob's claim in Genesis 32:21 that he has seen God face to face itself expresses a visual symmetry that gives Biblical ballast to the mutual gazing of $\S 164$. However, the rather startling innovative features of Heikhalot Rabbati need to be accounted for above and beyond their reliance upon Biblical and Rabbinic traditions, consisting as they do in a peculiar form of ocular visuality and God's extreme worship of Jacob's face.

Another Palestinian source, a liturgical poem of Yannai, the sixth century poet, comes close to the combination of affect, iconic imagery, and liturgical performance found in Heikhalot Rabbati:

Your trust is in Jacob

And the proof is Israel.

One who sees the image of Jacob

will sanctify the holy one of Israel.

\footnotetext{
${ }^{62}$ Genesis Rabba 82:2.

${ }^{63}$ Genesis 35:7. This theme is also found in Genesis 32:31 when Jacob names the place in which he was granted the name "Israel." He gives it the name, "Peniel" (פניאל, Face of God), "for I have seen God face to face (אל פנים כי ראיתי and my life was preserved."

${ }^{64}$ See Numbers Rabba, 4:1: Since you are precious in $\mathrm{My}$ sight. (Isaiah 43:4). The Holy One, Blessed Be He, said to Jacob: Jacob you are very precious in my sight. For I have set your icon on My throne, and by your name the angels praise Me and say: Blessed be the Lord, the God of Israel forever and ever (Ps. 41:14). This explains the biblical phrase,
}

And those who make mention of the name Jacob will venerate you God of Israel.

You are called the God of Jacob

And also the God of Israel.

And the exemplar of the camps of your angels,

This one will call out the name Jacob.

And this one will call out the name Israel.

This one will say he is holy

And this one will say he is blessed.

And they will call out to one another....

And they will encircle the chariot,

and rub with their wings. [...]

And they will prostrate their entire length to it.

And they will cover the Face of the throne. ${ }^{65}$

And a sound will emerge from its wheels.

[...] Their singing is to Jacob.

They sanctify you, Holy One of Jacob.

And they will respond and say:

"Holy, holy, holy. The Lord of hosts fills the entire earth with his glory."

From his place he [God] descended and brought down his hosts to see the image of Jacob.

In his place he [Jacob] was asleep; behold I [God] am with you because your image is with me.

In his place he slept; while you sleep your guardian will not sleep. ${ }^{6}$

It should be noted that despite the intersection of themes in this poem and Hekhalot Rabbati, specifically the liturgical setting evoked in both, Hekhalot Rabbati $\S \S 163-164$ places the liturgical in the human realm, whereas here besides the no-doubt liturgical environment in which the poem would be recited or sung, it is kept firmly in the angelic sphere. Crudely, put in (problematic) evolutionary terms, we can situate the Yannai poem in between the Rabbinic versions, and the more radical departures in the Heikhalot Rabbati reconfiguration, of the Jacob icon motif. ${ }^{67}$

The proximity between Yannai's oeuvre and Heikhalot literature has been discussed by a number of scholars. ${ }^{68}$ The points of contact with this poem and the Rabbinic Jacob-icon traditions are clear.

Since you are precious in My sight, and honorable.

${ }^{65}$ This expression invokes Job 26:9, "He covers the face of his throne," but in this setting must also work with the references to Jacob's image and facial features. Cf. $\S 164$, "I bend over it, embrace, kiss and fondle it."

${ }_{66}$ The Liturgical Poetry of Rabbi Yannai According to the Triennial Cycle of the Pentateuch and the Holidays, Vol. I, ed. Z.M. Rabinovitz, (Jerusalem and Tel Aviv: Bialik, 1985-1987), 168-169.

${ }_{67}$ This can tell us something about the likely post-rabbinic nature of Heikhalot Rabbati.

${ }^{68}$ See Ithamar Gruenwald's article on Yannai's poetry and its relationship to Heikhalot literature (including the relationship 
The blend of biblical and midrashic allusions, together with the lengths to which the poem goes in imagining a celestial liturgical ritual, is rather remarkable. Woven in are complex notions about the onomastic and representational function of Jacob as icon and name (Israel/God). The angelic worship, though clearly drawing from the same tradition as the Genesis Rabba midrash, goes much further in its description of the extent of the veneration through song and posture. An additional remarkable feature is God's descent with his angels to see Jacob. ${ }^{69}$ God himself is implicated in the desire to see his image. ${ }^{70}$

While the poem's overall themes adhere (with some great license) to rabbinic traditions, the inclusion of God's interest in Jacob's interest bears a strong affinity with Heikhalot Rabbati. To my knowledge, this element of tradition is not found in classical Rabbinic sources. Furthermore, differences of genres aside, nothing quite like the elaboration of image veneration is found either. ${ }^{71}$

between this poem and $\S 164)$, "The Poetry of Yannai and the Literature of the Descenders to the Chariot," Tarbitz, 36 (1967): 257-277. For Z.M. Rabinovitz's opposing arguments to the association of the Heikhalot with Yannai's poetry (including the materials under study here), see "On the Relationship of the Poet Yannai to the Literature of the Heikhalot and the Merkavah," Tarbitz, 36 (1967): 402-405. Elliot R. Wolfson refers to this poem in the context of his analysis of the Jacob image. See Wolfson, "The Image," 7. On the relationship, more between piyyut, Heikhalot and the Qedushah, see Ezra Fleischer, "The Diffusion of Qedushot of the 'Amidah and the Yozer in the Palestinian Jewish Ritual," Tarbitz, 38 (1969): 255-84 and Peter Schäfer, "Jewish Liturgy and Magic," in GeschichteTradition - Reflexion, Festschrift für Martin Hengel, ed. Peter Schäfer (Tubingen: Mohr Siebeck, 1996), 541-556.

${ }^{69}$ Of course this is implied, but not thematized, in the Hullin 91b tradition where God stands over Jacob to protect him from angelic wrath.

${ }^{70}$ Interestingly the terrestrial Jacob is also referred to as image.

${ }^{71}$ Perhaps, Genesis Rabba 7.10, where angels mistake Adam for a divinity and wish to recite "holy" to him, might qualify. While for comparative purposes, the impulse to recite Qedushah is notable, in that case the lack of ritualized embodied worship and God's decided discouragement still sets Yannai's poem and Heikhalot Rabbati apart.

${ }^{72}$ Cf. David Stern, Parables in Midrash: Narrative and Exegesis in Rabbinic Literature, (Cambridge, Mass: Harvard University Press, 1991), 110-113, on Lamentations Rabba 2.1. Stern rightly suggests that we should look to imperial and consular diptychs, medallions and busts that were set up at consular and judicial seats as inspiration for the Jacob icon. However, he goes on to suggest that the midrash, in which God threatens to cast down the Jacob icon, defuses the potential violence because it is "only an icon, a decoration." See p. 113. I disagree that the icon is a neutralizing image. Abuse of the imperial icon, like the religious icon, was a serious offense,

\section{§ 164: Facob's Image in Heikhalot Rabbati and Byzantine Image-Worship}

This brief account of the Jacob image's career on God's throne makes visible the extent to which $\S 164$ realizes, exploits and surpasses this motif. The icon is no mere decoration. ${ }^{72}$ Neither does it serve as a passive mnemonic. The text designates it as something that stimulates action and interaction ("that which I do to the cast of his face of his face") and that also reacts. ${ }^{73}$ What is it that gives rise to such graphic iconic imagery?

In order to fully account for the vividly iconic images deployed in $\S \S 154-169$, it is necessary to invoke Byzantine icon veneration. ${ }^{74}$ Cultural and art historians have demonstrated the increasing importance that the icon assumed in the sixth and seventh centuries in Byzantium. ${ }^{75}$ This growth in the popularity of icons was concurrent with the elaboration, expansion, and exegesis of liturgical practices. It is this environment that informs Heikhalot

and even in the complicated transpositions of roles between God/Israel/Jacob and Emperor/Icon/Populace, this sense could not have been lost.

${ }^{73}$ See also $\S 163$ where the descenders are importuned to report "what I do during the morning prayer." We will discuss the facial reaction in $\S 169$ below.

74 Acts of veneration towards images encompassed lighting candles in front of them, adorning them with veils, offering them flowers or incense, kissing them, touching them, bowing or prostrating before them, and praying before them. See George Galavaris, The Icon in the Life of the Church: Doctrine, Liturgy, Devotion (Leiden: Brill, 1981), for a recent version of the argument that practices of veneration were transferred from the imperial cult to Christian images. Similarly, Byzantine court "body-language" and ceremony became part of icon veneration. See Kenneth Parry, Depicting the Word: Byzantine Iconophile Thought of the Eighth and Ninth Centuries (Leiden: Brill, 2000), 8.

75 See, e.g., E. Kitzinger, "The Cult of Images in the Age Before Iconoclasm," Dumbarton Oaks Papers 8 (1954): 83-149; André Grabar, Christian Iconography: A Study of its Origins (Princeton: Princeton University Press, 1968); Peter Brown, "A Dark Age Crisis: Aspects of the Iconoclastic Controversy," English Historical Review 88 (1973): 1-34; Cameron, "The Language of Images," 1-42. They note that later sixth century sources in particular begin to mention the use and power of icons with increasing frequency. See further, Derek Kreuger, "Christian Piety and Practice in the Sixth Century," The Cambridge Companion to the Age of Justinian (Cambridge: Cambridge University Press, 2005), 291-215; E. Kitzinger, "Byzantine Art in the Period Between Justinian and Iconoclasm," The Art of Byzantium and the Medieval West (Bloomington: Indiana University Press, 1976), 45; Averil Cameron, "Images of Authority: Elites and Icons in Late Sixth-Century Byzantium," in Byzantium and the Classical Tradition, eds. M. Mullet and R. Scott. (Birmingham: Birmingham University Press, 1981), 205-34. 
Rabbati, so clearly suffused as it is with an almost exaggeratedly iconophilic sensibility. ${ }^{76}$

Indeed, it is an iconophilic sensibility that casts icons as objects that compel some kind of behavioral response on the part of the viewer. ${ }^{77}$ It was resolved in the Second Council at Nicaea that to capitalize on the commemorative function of the icon without enacting the desire for physical contact is to miss the point: ${ }^{78}$

As to those who say that it is sufficient to have the reproduction of icons as a means of remembering, without kissing them - thus accepting the one and rejecting the other - they seem to be half-wicked and falsely truthful. ... What insanity $!^{79}$

God's actions in Heikhalot Rabbati $\$ 164$ are in concord with the spirit of this declaration. Highly physicalized in nature they involve kneeling, embracing, kissing, and fondling the Jacob icon.

Interestingly, the object of these affections, the Jacob icon (or qlaster), is rendered in the feminine according to the verbs used in the Hebrew. ${ }^{80}$ Elliot Wolfson is rightly sensitive to the gender play at work, here especially in the feminization of the Jacob image. And yet, in this particular section, there is a rather more complex enactment of desire than heteroeroticism. ${ }^{81}$ To appreciate the ritual and liturgical language that is also at play in this performance, language that is to my mind redolent of Byzantine iconophile veneration, is also to recognize that God's "love-making" should be viewed as obeisant and self-subjugating rather than active and dominating. Like the constant switching off of subject and object in Heikhalot textuality, the gender roles and subject/object play here is unstable.

\footnotetext{
${ }^{76}$ This, taken together with echoes in liturgical poetry, points towards a wider deployment of iconic theological notions in Byzantine Judaism than might have been thought.

77 On this compunction, see Anna Kartsonis, "The Responding Icon," in Heaven on Earth: Art and the Church in Byzantium. ed. L. Safran. (University Park: Pennsylvania State University Press, 1998), 68-81.

${ }^{78}$ See Ambrosios Giakalis, Images of the Divine: The Theology of Icons at the Seventh Ecumenical Council, (Leiden: Brill, 1994), $117-129$.

${ }^{79}$ Proceedings of the second council of Nicaea trans. Daniel Sahas, Icon and logos:sources in eighth-century iconoclasm, (Toronto: University of Toronto Press, 1986), 364B.

${ }^{80}$ On the term qlaster see footnote 40 above. See $\S 164$ : For it/she is engraved [שהיא הקוקד] ... I prostrate over it/her [עלד] and kiss it/her [ומנשקד] and embrace it/her [ומחקות]] and fondle it/her [ומנגפקד]].

${ }^{81}$ See Wolfson, "Face of Jacob," 25-26, e.g., 26: "There
}

The Jacob icon may be feminized, but in ritual terms it is the dominant figure. This is where the Byzantine liturgical and ritual contexts enrich our understanding of the passage. Thus, at first glance, God's bow and kiss correspond to none other than the respectful and submissive postures of prostration (proskynesis) ${ }^{82}$ and kissing (apasmos) ${ }^{83}$ directed by any humble worshipper to icons of the sacred.

God's full-on embrace of Jacob is reinforced by his placement of his hands [ידיים] over Jacob's arms [זרעות]. This juxtaposition of body parts alludes to the biblical verse, "and the arms of his hands [זרועי ידיו] were made active, by the hands of the avir Jacob [מידי אביר יעקב]," another example of a biblical phrase whose interpretation also carries with it a history of Jacob's icon.

The cumulative effect of $\S 163$ and $\S 164$ 's adamant commitment to the visual witnessing of this scene, as well as the interlocked gaze of Israel and God, is that singing the Qedushah gives rise to God's passionate gestures to Israel via their heavenly representative, the icon of Jacob. As we have noted, this liturgically inflected and erotically charged iconophilic performance on the part of God towards the Jacob image is unprecedented in the (likely, earlier) incarnations of this motif.

In $\S 169$, a parallel section to $\S 163$, the yored is once again warned to relate what he has witnessed of the face:

A heavenly decree over you, you descenders to the chariot!

And if you will not tell [תנידו] you heard [ששמעתם]

is no question that in the above text the image of Jacob, or more precisely the visage . . of Jacob, is described vis-à-vis the divine king who sits upon the throne in terms befitting a feminine persona." Wolfson's reading of the God/Jacob interaction is heteroerotic in terms and depends on a gender stability that understands Jacob to be feminized to a(n already) masculinized God. It is true that God is "on top" and is apparently the "active partner" in this scene. It is also true that the mutuality that found in the exchange of gazes between God and Israel is apparently lacking here.

${ }^{82}$ Proskynesis seems to have meant either a hand-kissing gesture or prostration in the earlier Greek evidence. See Histories 1.134. Later, it describes gestures of veneration and obeisance more generally, and most often, specifically that of prostration (often used with piptein $=$ fall). In three instances the LXX translates kria as proskynein.

${ }^{83}$ Like proskynesis, aspasmos had the more general meaning of "greeting" or "salutation," but the term was used in the 
And if you do not bear witness [תעידו] to what you saw [מה שראיתם] on the face.

Face of elevation and might, exaltation and radiance, which is lifted up, is excited, and magnified

the face grows mighty and is magnified three times every day in the heights -

And no sons of man can know or recognize it as it says, holy, holy, holy.

It is very likely that the phrase "And no sons of man can know or recognize it" is an interpolation. ${ }^{84}$ Like Jacob who survives the vision of God's face, the descenders must go on not only in order to see, but to tell, about the facial magnificence.

This paragraph corresponds with God's treatment of Jacob's icon in $\S 164 .{ }^{85}$ But what exactly is "the face" here? Once again, it may refer to God's "face of Jacob," the same face that was such an object of praise in $\S 159$. Thus, having had God stoop over it, kiss, fondle and embrace it, God's "face" is now moved to excitement and expansion. ${ }^{86}$ The notion that icons of the sacred responded in various ways to worshippers (or attackers) was very much part of the cult of the images as it was developing in the sixth and seventh centuries. Icons secreted sweat, produced tears and bled. ${ }^{87}$

In light of these texts, the progression of allusions studded throughout the Qedushah hymns, and their eventual full exposure becomes clear. The Qedushah triggers the mutual vision of God and
Israel. Functioning as a literal mnemonic it "brings to mind Jacob (Israel)" whose facial icon God then adulates, and which in turns triggers the face's expansion. ${ }^{88}$ The mnemonic function that Jacob's icon serves in $\S 162$ (in the portion that immediately precedes $\S 163)$ is apparent:

Like the voice of the seas,

like the tumult of the rivers

like the waves of Tarshish disturbed by the southern winds,

like the voice of the throne of glory,

which brings to mind and praises the magnificent king, great voices and great tumult.

Voices move away from it/him, the throne of glory, to help it/him, to strengthen it/him,

when it/he calls to mind and praises the might [of] Facob [אביר יעקב].

As it is written, holy, holy, holy.

The idea of a heavenly icon of Jacob having a mnemonic, focusing, and even admonitory function resonates in late antique and Byzantine ideas about memory and images. ${ }^{89}$ This is found in Leontius of Neapolis' justification for images: "For this reason I depict Christ and his suffering in churches, in homes, market-places, and storehouses, in images on cloths and vestments, and in every place, so that the remembrance of them is always before my eyes, and never is neglected, as you have always disregarded the Lord your God." ${ }^{90}$ context of icon worship to denote kissing. This was one of the ways to greet an icon that was recommended by the Second Council of Nicaea (i.e. bowing, kissing, touching).

${ }^{84}$ This insertion is lacking in $\S 164$, the parallel to $\S 169$. Moreover, it is patent that "as it says, holy, holy, holy," follows the face that "grows might and is magnified three times every day in the heights." Reinforcing this three-fold magnification and sanctification is the three-fold description that immediately precedes that of the face being "lifted up, excited and magnified."

${ }^{85}$ See Kuyt, Descent, 173.

${ }^{86}$ For more possible allusions to the responsive Jacob icon see $\S 165$ where the wonders and miracles that happen every day "before God" are described. Perhaps what is actually referred to (given this section's placement) are the wonders that occur on his face. This reading is quite plausible as the word for "before him," lepanav, could also read "to his face."

${ }^{87}$ We see this in the miracle stories of the period. See the extensive discussion in Kitzinger and Cameron. For an analysis of this responsiveness on the part of images, see Kartsonis, "Responding Icon," 68-81. On the ways in which icons miraculously reacted like bodies (e.g. bleeding when attacked), see Peers' analysis in Sacred Shock, 45-49.
${ }^{88}$ One should also not forget the long tradition of falling in love with images and statues. See Deborah Steiner, Images in Mind: Statues in Archaic and Classical Greek Literature and Thought (Princeton: Princeton University Press, 2001). In this regard and also with regard to Jacob's expanding face, the animation of images is also to be explored. On the role of images in visual memory in Byzantine visual theory (given that memory itself was understood as visual), see Liz James, "Art and Lies: Text, image and imagination in the medieval world," in Icon and Word: The power of images in Byzantium, eds. Liz James and Antony Eastmond, (Aldershot: Ashgate, 2003), 59-72, esp. p. 65, "The material world mattered to the Iconophiles because it was visible. When Leontios listed ways of venerating the Creator, the element that bound them together was that they could be seen. The sight of the holy Places recalls Christ, brings him to the mind's eye ... It is a remembrance .. . through sight."

${ }^{89}$ See Isaiah 49.1 where God calls Jacob from his mother's womb, mentions his name (hizkir sh'mi) from her loins. Cf. Yannai on Gen. 28: 12, "And those who make mention of the name Jacob, will venerate you God of Israel."

${ }^{90}$ Leontius of Neapolis (590-650 CE), Against the Fews, PG 93, 1597-1612, (Anderson trans., 99-100.) 
The notion of the image as a deterrent to sin is also found in rabbinic traditions about Jacob's image that are extracted from Genesis 49:24:

But his bow remained firm, and the arms of his hands [זרעי ידיי] were made supple, by the hands of the mighty one of Jacob [מידי אביר יעקב] .. .

These traditions see in this verse allusions to Joseph's attempted seduction by Potiphar's wife. The rabbis argue that in fact Joseph almost succumbed to temptation. ${ }^{91}$ Most fortunately an icon of his father Jacob materializes chilling his ardor (his bow remained firm) and causing his semen to seep out of his fingers [זרעי ידיו]. ${ }^{92}$ Here, a reference to God as "the mighty one of Jacob" [אביר יעקב], becomes an epithet for Jacob himself. ${ }^{93}$

Whether or not Heikhalot Rabbati is alluding to Genesis 49.24, its rabbinic interpretations, or the host of biblical references to Jacob/Israel and the mnemonic name, it is noticeable that language of name-mentioning, recollection and allusions to Jacob are scattered throughout this section. ${ }^{94} \mathrm{We}$ might perhaps include in this count, $\S 154$, where God sitting on the throne is supposed to elicit the jubilation of "whole seed of Jacob [זרע יעקב];" in § 162 where something about the throne that

\footnotetext{
${ }^{91}$ See Genesis Rabba 98.20 and Babylonian Talmud Sotah 49b.

${ }_{92}$ Where arms [זרע] become seed [זרעי] and the hands in question [ידיר] are the place to which his misplaced desire is redirected and the place from which it is scattered [יויפזר].

${ }_{93}$ This is another instance of the way in which Jacob can stand in for God (and vice versa).

${ }^{94}$ See $\S 156$ where it (implied) that the singularity of the yored is compared to God's angelic retinue. Among the distinctions listed is that "When one recalls the name of one of you (Jacob?) [המזכיר שם אחד מכם], fire glows, flame surrounds, sparks fly ..." See $\S 162$ (as above): recollection, mentioning (zikaron features twice, once with respect to avir ya akov; § 165: "when they mention that name;" $\S 166$ : "for in the place that they mention it/him, it shines and streams and glows golden and silver..." (the name is then referred to as that with which creation was wrought, more likely a divine name); $\S 168$ : (directed to bearers of throne who) "mention and sound to him the mention/remembrance of his name."

${ }_{95}$ Brown, 7, 10, "The icon was a hole in the dyke separating the visible world from the divine, and through this hole there oozed precious driblets from the great sea of God's mercy.... The rise of the cult of icons... in the sixth and seventh centuries, and not the origins of Iconoclasm - this is the central problem of the Iconoclast controversy." See further Brown, 11: "Byzantines of the sixth, seventh and eighth centuries were getting from the icons what they never expected to get from an imperial image - they got the miracle of healing and the greater miracle of a flood of tears of repentance for their sins," and Brown, 15: "The momentum of the search for a face made itself felt throughout the sixth century in
}

"brings to mind and praises the might of Jacob [אביר יעקב]; and in § 164 when God's hands are on Jacob's arms [וידיי על זרעותי]. One can speculate whether it is plausible that, in a passage that so prominently features Jacob's image in such an eroticized manner, this Rabbinic tradition about אביר יעקב is in the mix. If so, it is at play quite differently; rather than serving to cool passion, here Jacob's image stokes it.

\section{The Figure of the Jew and the Icon of the few in Byzantium}

The texts of this pre-iconoclastic era evince a palpable desire for real and intimate contact with the sacred. ${ }^{95}$ I would argue that a similar desire is also discernable in Heikhalot Rabbati, even if it is projected onto the figures of Jacob and God. As well as the "rise of the cult of images," seventh centuries witnessed an increase in antiJewish writing. ${ }^{97}$ In this "age before iconoclasm"98 heated debates that would become part of the official iconoclastic controversy about the nature of physical matter, representation and Christ were already underway. ${ }^{99}$ The figure of the Jew played its part in all this.

changes in the traditional type of relics. Icons came to join the relic.... The icon was the go-between."

${ }_{96}$ As per Kitzinger's title, "The Cult of Images in the Age before Iconoclasm."

${ }^{97}$ See Cameron, "The Language of Images," 481. The slippery figure of the Jew is not unlike that of the "Judaizer;" indeed, Cameron notes, the two can be hard to distinguish. See Cameron, "Heresiology," 474. Of the iconoclastic era she observes that, (481): "Not surprisingly, heretics are also, and even more frequently, equated with Jews, in an elision of anti-Jewish, antiheretical, and anti-iconoclast rhetoric." See further idem, "Jews and Heretics-A Category Error?" in Reed and Becker, eds., "The Ways," 345-360.

98 "Iconoclasm" refers to the official imperial policy against images launched by Emperor Leo III in Constantinople in $730 \mathrm{CE}$.

${ }^{99}$ For an arguably earlier iconophilic dialogue between two Christians (an "Orthodox" iconophile and a non-iconophile) see Alexander Alexakis, "The Dialogue of the Monk and Recluse Moschos concerning the Holy Icons: An Early Iconophile Text," Dumbarton Oaks Papers, 52, (1988): 187-224. Alexakis believes that the Dialogue was written in the second third of the fifth century. While this dialogue is between two Christians, many of the arguments used appear in later anti-Jewish dialogues of the first half of the seventh century. Furthermore Jews, or accusations of "Judaizing," are not part of that argument, leading Alexakis to conclude that the dialogue "must have come from a period before the entrance of the Jews into the dogmatic disputations related to the worship of man-made objects, that is, before the seventh or even the 
A dialogue between a Christian and a Jew by Leontius of Neapolis brings together the adversus fudaeos tradition with iconophilic arguments in the figure of the Jew who accuses icon-venerating Christians of idolatry. ${ }^{100}$ This voice, defending itself against an ostensibly Jewish charge of idolatry, reaches us from the first part of the seventh century and joins a veritable chorus of anti-Jewish arguments. ${ }^{101}$

When I honor the image of Christ, I am not worshipping wood and paint. God forbid! But when I venerate an inanimate image of Christ, it seems that I touch and worship Christ himself. [...] In the same way, when we Christians embrace the icons of Christ, or an apostle, or a martyr, with a physical kiss, we give a spiritual kiss to Christ himself, or his martyr. [...] See how many embraces and how much worship I have made evident to you, both from Scriptural evidence and natural instinct. You will condemn none of these, yet no sooner do you see someone venerating the icon of Christ, or his all-holy mother, or one of the saints, than you become angry, and blaspheme, calling me an idolater. ${ }^{102}$

Leontius' argument enlists the ubiquity of the icon and its mnemonic use, not only as proof of its utility, but also as a reproof against the Jewish failings in this very regard (that is, the Jewish failure to remember and consequent tendency to transgress). The Christian images, which are housed in sacred spaces, as well as in the domestic and commercial spheres, are there "so that the remembrance of them is always before my eyes." Seeing, then, is an act of recollection and memory.

An interesting conception of representation also underpins the argument. It is at once Platonic and materialist. It claims to deny the tendency toward idolatry in the rejection of materialism: "When I honor the image of Christ, I am not worshipping wood and paint." However, at the same time it posits the material as an apparently physical bridge to what is represented: "But when I venerate an inanimate image of Christ, it seems that I touch and worship Christ himself." The example of Jacob is cited in the same vein: "When Jacob received Joseph's coat of many colors from his brothers who had sold him he caressed it and wept as he gazed upon it. He was not weeping because of the coat, but it seemed to him that by embracing the coat he embraced Joseph, and held him in his arms." While paradoxical, the promise is powerful: gazing at an image, touching it, embracing it and kissing it, are ways of seeing, touching, holding and kissing its prototype. Alongside the defensive and apologetic function of the argument, the desire to interact with sacred is tangible in this text. ${ }^{103}$

It is just this tantalizing blurring between the material object and what it represents ${ }^{104}$ that provokes the specter of idolatry raised by the Jewish interlocutor. ${ }^{105}$ The work of the dialogue is to hurl the accusation back at the accuser thus maintaining the Christian integrity of iconophiles as well as marking Jewish-Christian difference.

This distinguishing between good and bad kinds of images and, indeed, good and bad kinds of looking, can be observed in Yannai, the sixthcentury Palestinian liturgical poet, who directs some harsh rhetoric against Christian practices of image veneration which sit rather well with contemporaneous Christian representations of antiiconic Jews: ${ }^{106}$ late sixth century." On the figure of the Jew in visual polemics about images in the ninth century see Katherine Corrigan, Visual Polemics in the Ninth-Century Byzantine Psalters, (Cambridge: Cambridge University Press, 1992.

${ }^{100}$ In this regard it is does not stand alone in the preIconoclastic period. See above, note 6 . The link between debates about icons and anti-Jewish writing has been noted by Deroche in "la polemique anti-Judaique au Vie et au VIIe siecle," Kephalaia, TM 11, (1991): 275-311, at 281. See also N. H. Baynes, "The Icons Before Iconoclasm," Harvard Theological Reviewe, 44, (1951): 93-106.

101 Alexakis, 187-224.

${ }^{102}$ Leontius of Neapolis (590-650 CE), Against the Feres, PG 93, 1597-1612, Anderson trans., 99-100.

${ }_{103}$ Brown, 7-15.

${ }^{104}$ See Peers, 45, on the way in which the "phenomenon of icons as bodies, that is, as objects that exhibit signs famil- iar to real bodies, such as blood, tears, and motion," is exemplified in Pseudo-Athanasius's Quaestiones ad Antiochum Ducem. Peers describes how "the relationship between image and model was easily collapsed, if not totally, then at least to the point of partial identity."

${ }^{105}$ See Cameron, "The Language of Images," 481: "Jews may have accused Christians of idolatry, but the Christian argument itself was about signification, what signified and how." The "but" in this sentence should be reconsidered. Christian representations of Jews as accusing Christians of idolatry may or may coincide with actual accusations. However, this does not exclude the fact that Jews themselves were invested in similar issues of signification and representation. To the extent that they weighed in on Christian image worship, this too was part of a similar preoccupation.

${ }^{106}$ See Rabinovitz, ed., Vol. 2, 221-2. See citation and translation in Fine, 117. 
Who say to nothingness, "save!"

Who chose the disgustingly repulsive,

Who rejoice in statues of human figures,

Who cleave to the dead over the living...

Who prostrate and pray to a bush and are prostrated ...

Who acquire assemblages of bone

Who moan to them on their festivals....

The same Yannai, however, was also responsible for the liturgical poem about the image of Jacob that we saw above. In that instance he sounded in rich visual imagery. Given Yannai's rough treatment of Christian image worship, it is especially curious that Jacob's image triggers veneration and liturgical outburst by God's angelic host. Also noteworthy is the iconic relationship and function that Jacob's image (and name) has with respect to God. The wrong image is repulsive; the right one evokes and invokes God.

Thus, we find a complex of Jewish conceptions of visuality at play in the liturgical poetry of the Byzantine synagogue, one that belies the notion of a Jewish anti-iconophobia or anti-visualism. ${ }^{107}$ The flowering of visual representation in the Palestinian synagogues themselves also confirms this picture.

Recalling Fine's comment on the use of images and attitudes towards them as ways of forming identity and drawing boundaries in the Byzantine period, we may also consider that Heikhalot Rabbati § 154-164 participates in debates about, negotiates its way among, or at the very least appropriates themes of, the specifically contentious meeting of issues such as icon veneration, idolatry, and Jewishness.

As Herbert Kessler observes, a recurrent theme in Christian literature and images, is that because the Jews rejected Christ they were denied direct vision of God enjoyed by Christians. ${ }^{108}$ Related Jewish visual problems rendered them peculiarly susceptible to idolatry. But, while the Jew may have needed to adhere to the second commandment, the Christian is able to distinguish between icon and idol, between veneration and worship. ${ }^{109}$

Given the iconodulic identification of Jew and iconoclast (or heretic), and Jew and idolater, as well as the non-too subtle claim to legitimacy at the expense of Jewish/iconoclastic illegitimacy, we may wonder about how the deployment of imagery of icon-worship functions in the Heikhalot hymns. Perhaps we can even speak of $\S \S 154-164$ as a Jewish attempt to appropriate iconophilic imagery to make (counter)claims about Jewish legitimacy. ${ }^{110}$ Similarly, if the pre-Iconoclastic debates were as much about Christology and representation as they were about image worship as such, then perhaps the image of Jacob's icon has a peculiar salience in this regard. ${ }^{111}$

One question about the figure of the Jew in the sixth and seventh century anti-Jewish texts is whether "real Jews" stand behind such representations. ${ }^{112}$ Did debates between Jews and Christians really take place or were Jewish interlocutors rhetorical constructs or substitutes for "Judaizers"

\footnotetext{
${ }^{107}$ Similarly, even Christian iconoclasts were not necessarily against all forms of representation. Cameron characterizes the debate between iconoclasts and iconophiles as deriving from the debate about representation, the literal and the figurative. For example, at stake was whether the cross and the Eucharist were the correct ways to represent Christ.

${ }^{108}$ Herbert L. Kessler, Spiritual Seeing: Picturing God's Invisibility in Medieval Art (Philadelphia: University of Pennsylvania Press, 2000), especially Chapter 2.

${ }_{109}$ Fascinatingly, Epiphanes the Deacon, in the seventh council of Nicaea, distinguishes holy icons from "those things which are for the glory and memory of the demons and are made by the Greeks and the Jews who worship them." See Sahas, "Icon," 248B. Katherine Corrigan demonstrates how in later (ninth century) illustrated Byzantine Psalters the Christian's ability to distinguish between icon and idol is argued with visual force. See Corrigan, p. 35, where she further argues that these images that showed Jews as idolaters
}

were in circulation well before the ninth century.

${ }^{110}$ For related arguments see David Biale, "Counter-history and Jewish polemics against Christianity: the 'Sefer Toldot Yeshu' and the 'Sefer Zerubavel,"' Fewish Social Studies 6 (1999): 130-145; Martha Himmelfarb, "Sefer Zerubbabel," Rabbinic Fantasies: Imaginative Narratives from Classical Hebrew Literature, eds. David Stern and Mark J. Mirsky, repr. (New Haven: Yale University Press, 1998), 67-90; Peter Schäfer, Mirror of His Beauty: Feminine Images of God from the Bible to the Early Kabbalah, (Princeton: Princeton University Press, 2004), 212-216.

${ }^{111}$ Further, if pre-Iconoclastic Byzantium was marked by intensification in liturgical development and exegesis, what light can this shed upon the obviously liturgical character of both form and content of this section of Heikhalot Rabbati? The relationship between early Byzantine piyyut and contemporaneous Christian hymnody has been noted. See, recently, Lee Levine, "The Synagogue," 528-531.

${ }^{112}$ See footnotes 7 and 8. 
or other groups? ${ }^{113} \oint \S 154-169$ of Heikhalot Rabbati may not allow us to answer this question directly, but at the very least it does reinforce and also complicate the picture of Jewish-Christian contestedness relating to icons. Whether Jews or Christians as iconodules or iconophobes were talking to, past, or about, each other, it does seem likely some Jews and many Christians were working within the same discursive sphere.

While the Byzantine justification for images depended in part on Christ's material and visual incarnation, ${ }^{114}$ it was still important to distinguish between appropriate and inappropriate behavior towards images, and so to preserve the distinction between veneration of icons, and worship of the prototype (e.g. Christ) that it represented. One can still detect a good dose of anxiety at work in the careful distinctions between right and wrong kinds of devotional behaviors, even towards the end of the eighth century. ${ }^{15}$

By contrast, in Heikhalot Rabbati, God's actions seem to be nothing short of intensely iconophilic behaviour amounting to "true worship" (latreia)what starts off with a liturgical setting for the Jacob icon ends up going well beyond the proskynesis and aspasmos eventually mandated by Byzantine theologians and officials to delimit appropriate behavior. ${ }^{116}$ What the good Byzantine theologian wanted to avoid was the slippage between image and its referent, as well as the whiff of idolatrous pagan practice. But the divine behaviour set into play by the utterance of the Qedushah forgoes such refined theological niceties.

We know that people did not only gaze at material objects of representation such as icons and relics; they kissed, touched, embraced, held, and even nibbled and swallowed. ${ }^{117}$ And, indeed, it has been argued that iconoclasts and iconophiles were actually going about the same project of domesticating these unruly objects of devotion and liturgical excess. ${ }^{118}$ Iconophiles accomplished this in part by projecting undesirable behavior onto Jews and by making Jews into iconophobes. This served to underpin the rhetoric about Jewish blindness to God's eikon, (Christ) which played a part of the debate about representation and Christology. Seen in this way, the image of Jacob and the emphasis on ocularity (and more) in Heikhalot Rabbati can be seen to be the functional equivalent of, or the Jewish "answer" to, the Christ icon.

In the Heikhalot Rabbati text, this eikon is firmly embedded in the liturgical context of the synagogue and yet the veneration, or better, the emphasis of the embodied worship, seems to take place exclusively in the heavenly realm. In this realm, which is also the realm of the visionary, passionate excess is the order of the day; no theological constraints hold God back. It is as if the Jacob icon's potency lies not only in its reversal of the usual religious dynamic whereby God is the object of worship, but also in its passionate upstaging of the form that this worship takes.

The text of the Qedushah hymns constitutes a performance, not so much of the experience of the mystical practitioner, the yored, but of an interaction between God and Israel. Viewed against the backdrop of the pre-Iconoclast era, we see the two-sided image of the Jewish inclination toward idolatry and iconoclasm, thrust and projected heavenwards onto God, thereby turning the less than complimentary image into ultimate praise. Even if polemical intent cannot be established,

\footnotetext{
113 See footnotes 8 and 77. e.g. see Sidney Griffith, "Abū Qurrah's," Journal of the American Oriental Society 105.1 (1985): 62.

114 One finds this explicit argument in the eight century sources, although a version of it is also present in PseudoAthanasius's Quaestiones ad Antiochum Ducem.

${ }^{115}$ In 787, the Seventh Ecumenical Council of Nicaea distinguished between acts of veneration (proskynesis) and worship (latreia). The latter was to be offered to icons whereas the former belonged only to the "divine nature."

${ }_{116}$ The prohibition against idolatry in Exodus 20:45 prohibits the bowing down to idols, "you shall not bow down to them." This was rendered proskyneo in the Greek - the very
}

verb usually used to describe the usual worship of legitimate objects of veneration. See also the combined use in Revelations $4: 6-8$, where the 24 elders fall (pipto) before the throne of God and worship him (proskyne $\overrightarrow{0}$.

117 See Anthony Cutler, The Hand of the Master: Craftsmanship, Ivory and Society in Byzantium (9th-11th Centuries) (Princeton: Princeton University Press, 1994), as well as his "A NewlyDiscovered Byzantine Ivory and Its Relatives in London," The Burlington Magazine 136 (1994): 430-433. In both of these works Cutler shows how the wearing of surfaces of Byzantine ivory images show that they were touched, held, rubbed and kissed in devotional practices.

${ }^{118}$ See Brown, "Dark Ages," 6. 
the patent deployment of Christian practices of image veneration must contain some element of one-upmanship. ${ }^{119}$ Surely, those religionists who must be content with liturgical and devotional practices revolving around earthly icons are "superceded" by those singular people, on whose iconic representation/representative in heaven God wants nothing more than to heap his passionate adoration.
19 Furthermore, the ascendancy of Jacob/Israel over the angels (both in terms of his proximity to God on the divine throne and in his battle), at least via its deployment in this textual unit, can be viewed not only as part of the angelic- human rivalry but as a declaration about which Israel ("new" or "old") is ascendant, which, in the Byzantine environment, may be seen as part of a theological (or counter-Christological) polemic. 